\title{
Two Councils by A.N. Maykov in F.M. Dostoevsky's Novel The Brothers Karamazov
}

\author{
Boris V. Sokolov \\ AIRO-XXI, Moscow \\ $\triangle$ bvsokolov@yandex.ru
}

\begin{abstract}
The article is devoted to the issue of reception of the poems about Catholic Church written by A.N. Maykov, a close friend of F.M. Dostoevsky, in his novel The Brothers Karamazov and, above all, in "The Legend of the Grand Inquisitor". We are talking about the poems - "The Queen's Confessions. The Legend of the Spanish Inquisition", "Sentence. The Legend of the Constance Council" and "The Legend of the Clermont Council". It is "The Queen's Confessions" which led Dostoevsky to make Seville the setting for the "Legend of the Grand Inquisitor". The main character of the "Sentence", Cardinal Hermit, became the prototype of the Grand Inquisitor in Dostoevsky's novel, and the main character of "The Legend of Clermont Council", the Pilgrim Hermit, in many ways became the prototype of the unrecognized Christ from the "Legend of the Grand Inquisitor". The article presents significant textual parallels between Maykov's poems and The Brothers Karamazov.
\end{abstract} sources

Keywords: A.N. Maykov, F.M. Dostoevsky, The Brothers Karamazov, prototype, literary

Conflicts of interest. The author declares that there is no conflict of interest.

Article history: submitted: June 7, 2021; accepted: July 7, 2021.

For citation: Sokolov, B.V. (2021). Two Councils by A.N. Maykov in F.M. Dostoevsky's Novel The Brothers Karamazov. RUDN Journal of Studies in Literature and Journalism, 26(3), 442-450. doi: 10.22363/2312-9220-2021-26-3-442-450

\section{Два «Собора» А.Н. Майкова \\ в романе Ф.М. Достоевского «Братья Карамазовы»}

\author{
Б.В. Соколов \\ АИРО-ХХІ, Москва \\ $\triangle$ bvsokolov@yandex.ru
}

Аннотация. Статья посвящена отражению стихотворений близкого друга Ф.М. Достоевского, посвященных католической церкви, в романе «Братья Карамазовы» и прежде всего в «Легенде о Великом Инквизиторе». Речь идет о поэмах - «Исповедь Королевы. Ле- 
генда об испанской инквизиции», «Приговор. Легенда о Констанцском соборе» и «Легенда о Клермонтском соборе». «Исповедь королевы» подсказала сделать местом действия «Легенды о Великом инквизиторе» Севилью. Главный герой «Приговора», кардинал пустынник, стал прототипом Великого Инквизитора в романе Достоевского, а главный герой «Легенды о Клермонтском соборе», пилигрим пустынник, во многом стал прототипом неузнанного людьми Христа из «Легенды о Великом инквизиторе». В статье приводятся значимые текстуальные параллели между стихотворениями Майкова и «Братьями Карамазовыми».

Ключевые слова: А.Н. Майков, Ф.М. Достоевский, «Братья Карамазовы», прототип, литературные источники

Заявление о конфликте интересов. Автор заявляет об отсутствии конфликта интересов.

История статьи: поступила в редакцию - 7 июня 2021 г.; принята к публикации 7 июля 2021 г.

Для цитирования: Sokolov B.V. (2021). Two Councils by A.N. Maykov in F.M. Dostoevsky's novel The Brothers Karamazov // Вестник Российского университета дружбы народов. Серия: Литературоведение. Журналистика. 2021. Т. 26. № 3. С. 442-450. doi: 10.22363/2312-92202021-26-3-442-450

\section{Introduction}

June 4, 2021 marks the 200th anniversary of the birth of the poet Apollon Nikolaevich Maykov, a friend of Fyodor Mikhailovich Dostoevsky. This friendship is reflected in Dostoevsky's last novel, The Brothers Karamazov. For the first time Dostoevsky told Maykov about the idea of the novel Atheism, from which The Brothers Karamazov (1878-1880) grew, in a letter dated October 11, 1868: "Here I have a huge novel on my mind now, the name of it is «Atheism» (for God's sake, only between us), but before starting it, I need to read almost a whole library of atheists, Catholics and the Orthodox" [1. Vol. 28. Book 2. P. 477].

Echoes of some of Maykov's poems are found in The Brothers Karamazov and, first of all, in "The Legend of the Grand Inquisitor" - an insert parable in the form of Ivan Karamazov's story about his poem in the 5th chapter of "The Grand Inquisitor" of the 5th book "Pro and Contra" of the 2nd part of the novel. This parable is a counterpoint to The Brothers Karamazov.

\section{Discussion}

As it was noted by Vera S. Nechaeva, in connection with the poem of A.N. Maykov "The Legend of the Spanish Inquisition" (1861, book 1) published in the magazine of the Dostoevsky brothers "Vremya" ("Time"), "the very name 'The Legend of the Grand Inquisitor', the external features of the image created by Dostoevsky, and the peculiarities of its voice appeared under the writer's pen not without the memory of the first book of 'Vremya' where Maykov's 'Legend' appeared" [2. P. 209-210].

But traces of the "Legend of the Spanish Inquisition" are found not only in the "Legend of the Grand Inquisitor", but also at least in one other chapter of The 
Brothers Karamazov. In "The Queen's Confessions”, subtitled "The Legend of the Spanish Inquisition", Queen Isabella of Castile confesses that:

\section{This morning a camarera \\ I scolded \\ And pricked her with a pin her... \\ I was so ashamed afterwards... [3. P. 246]}

This unjust punishment is caused by the Queen's secret love for Don Juan, who turns out to be her confessor.

In The Brothers Karamazov a similar motif can be observed. General Vorokhov's widow, seeing that the children of Fyodor Pavlovich Karamazov are not well groomed, slaps her valet Grigory: "Having noticed at first glance that they are not washed and in dirty clothes, she immediately slapped Grigory and announced that she was taking both children to her home, then took them out in what they were, wrapped them in a blanket, put them in a carriage and took them to her city. Grigory bore this slap in the face like a devoted slave, did not say a word, and when he accompanied the old lady to the carriage, he bowed to the waist for her, and enunciated in a solemn manner 'the Lord will reward you for the orphans"" [1. Vol. 14. P. 14].

The general's widow is called "not an evil" old woman, but the one "who was only an unbearable tyrant because of her idleness" [1. Vol. 14. P. 13].

The Brothers Karamazov also absorbed some other works by Maykov. When drinking Mitya Karamazov quotes the final lines of A.N. Maykov's poem "Basrelief" (1842), where the satyr Silenus, the supporter and educator of Dionysus, the ancient Greek god of wine and fertility, was mentioned [1. Vol. 14. P. 98; Vol. 15. P. 542]. The quote from Maykov shows that there are more hidden references to Maykov's works in the novel.

As we have already written, the poem "Sentence. The Legend of the Constance Council" by A.N. Maykov became one of the main sources of the "Legend of the Grand Inquisitor" in The Brothers Karamazov [4].

The nihilist and atheist Ivan Karamazov tells his brother Alyosha, who wanted to become a monk, the content of his poem written in his youth. Its main character, the Grand Inquisitor, the personification of the Catholic reaction, acting in Seville of the XVI century, met Christ, in whose name he punished heretics. And the Savior, who came into the world for the second time, was not only unnecessary to him, but simply harmful. The ninety year old cardinal comes to the cell to Jesus and convinces Him of the perniciousness of the path of salvation offered by Him.

Here is the description of the Grand Inquisitor: " $<\ldots>$ Cardinal Grand Inquisitor. He is an old man of almost ninety, tall and straight, with a withered face, with sunken eyes, but from which a gleam still shines like a spark of fire". He is "in his old, coarse monastic robe" [1. Vol. 14. P. 227]. 
Ivan Karamazov emphasizes that "my old inquisitor, who himself ate roots in the desert and raved, overcoming his flesh in order to make himself free and perfect, but nevertheless, all his life he loved humanity and suddenly saw that it was not a great moral bliss to achieve the perfection of the will, so that at the same time to become convinced that millions of other God's creatures were left only in mockery, that they would never be able to cope with their freedom, that no giants will come out to complete the tower, that it was not for such geese that the great idealist dreamed of his harmony" [1. Vol. 14. P. 238]. The inquisitor "killed his whole life for a feat in the desert and was not cured of his love for humanity" [1. Vol. 14. P. 238].

Ivan tells Alyosha: "The old man himself remarks that He has no right to add anything to what has already been said. In fact, this is the most basic feature of Roman Catholicism... 'Everything, they say, has been handed over by You to the pope and so everything is now with the pope, and do not come at all now, do not interfere until the time comes at least'...".

"Do You have the right to tell us any of the secrets of the world where You came from? - my old man asks Him, and answers for Him himself, 'No, you don't, so as not to add to what has already been said before, and so as not to take away from people the freedom for which You stood when You were on earth. Everything You proclaim again will encroach on the freedom of people's faith, for it will appear as a miracle, and the freedom of their faith was dearer to You than anything else back then, fifteen hundred years ago. Didn't You say so often back then: 'I want to make you free'. But now You have seen these 'free' people, the old man suddenly adds with a thoughtful smile. 'Yes, it cost us dearly', he continues, looking at Him sternly', but we have finished it at last, in Your name. For fifteen centuries we have suffered with this freedom, but now it is over and it is over firmly. Don't you believe it's over? You look at me meekly and don't even deign to resent me? But know that now, and just now, these people are more sure than ever that they are completely free, and yet they themselves have brought us their freedom and have submissively laid it at our feet...".

"For now only (he is, of course, talking about the Inquisition) it became possible to think for the first time about the happiness of people. Man was made a rebel; how can rebels be happy? You were warned, he says to Him, You had no lack of warnings and instructions, but You did not listen to the warnings, You rejected the only way to make people happy, but fortunately, when You left, You gave us the right to bind and untie, and certainly You cannot think of taking away from us this right to create. Why did You come to interfere with us?.." [1. Vol. 14. P. 228-229].

"You want to go into the world, and you go with your bare hands, with some vow of freedom, which they, in their simplicity and in their innate outrage, cannot even comprehend, which they fear and dread for nothing has ever been more unbearable for man and human society than freedom! And do you see these stones in this naked hot desert? Turn them into loaves, and mankind will run after You like a flock, grateful and obedient, though always trembling, that You will take away Your hand and Your bread will be cut off for them". 
"But You did not want to deprive a person of freedom and rejected the offer, for what kind of freedom, You reasoned, if obedience is bought with bread? You have objected that man does not live by bread alone, but do you know that in the name of this very bread of the earth the spirit of the earth will rise up against You and fight with You and overcome You, and all will follow him, exclaiming: 'Who is like this beast, he has given us fire from heaven!' Do you know that centuries will pass, and humanity will proclaim through the mouth of its wisdom and science that there is no crime, and therefore there is no sin, but only the hungry. 'Feed them, then ask them for their virtues!' - they will write these words on the banner that they will raise against You and with which Your temple will be destroyed. On the site of Your temple, a new building will be erected, the terrible Tower of Babel will be erected again, and although this one will not be completed, like the old one, but still You could avoid this new tower and reduce the suffering of people for a thousand years, because they will come to us after suffering for a thousand years with their tower! They will then find us again underground in the catacombs, hiding (for we will again be persecuted and tormented), find us and cry out to us: 'Feed us, for those who promised us fire from heaven did not give it'. And then we will build their tower, for the one who will feed them will finish it, and only we will feed them, in Your name. Oh, never, never will they feed themselves without us! No science will give them bread as long as they remain free, but they will end up bringing their freedom to our feet and saying to us, 'Rather enslave us, but feed us'. They will finally understand for themselves that freedom and the bread of the earth are unthinkable for everyone together, because they will never, never be able to divide among themselves! They will also be convinced that they can never be free, because they are weak, vicious, insignificant, and rebellious. You promised them the bread of heaven, but, I repeat again, can it compare in the eyes of a weak, eternally vicious and eternally ungrateful human race with the earthly one? And if thousands and tens of thousands follow You in the name of the bread of heaven, what will become of the millions and tens of thousands of millions of beings who will not be able to neglect the bread of the earth for the heavenly? Or do You value only tens of thousands of the great and strong, and the remaining millions, numerous as the sand of the sea, weak, but loving You, should only serve as material for the great and strong? No, the weak ones are also dear to us. They are vicious and rebellious, but in the end they will also become obedient. They will marvel at us and will consider us as gods because we, having become their head, agreed to endure freedom and rule over them - so terrible will it become for them to be free in the end!" [1. Vol. 14. P. 230].

The finale of the poem is as follows: "<..> He suddenly silently approaches the old man and quietly kisses him on his bloodless ninety year old mouth. That's the whole answer. The old man shudders. Something moved at the ends of his lips; he went to the door, opened it, and said to him, 'Go and come no more... don't come at all... never, never!' and releases it on the 'dark hailstones'. The prisoner leaves. $<\ldots>$ The kiss burns on his heart, but the old man remains with the same idea" [1. Vol. 14. P. 239]. 
The Grand Inquisitor, who carried out the punishment in Seville in the XVI century, does not have a historical prototype, like the notorious Thomas Torquameda (1420-1498), who, by the way, was not ninety years old, like the hero of the "Legend of the Grand Inquisitor", but only seventy-seven years old, and he lived in the XV, not in the XVI century. The Grand Inquisitor has a very specific literary prototype, one of the heroes of A.N. Maykov's poem "The Sentence", which is subtitled "The Legend of the Constance Council". In Dostoevsky's case it is the "Legend of the Grand Inquisitor", titled as poem, in Mayakov's case it is the poem, subtitled as "The Legend of the Constance Council".

The "Legend of the Council of Constance" refers to the sentence that the Catholic Council passed on the heretic Jan (Johan) Huss (1369-1415), a popular Czech preacher of the early XV century, who in the XVI century was already considered as a precursor of the Protestant Reformation.

Maykov wrote "The Sentence" in 1860, eight years before Dostoevsky conceived the idea for the novel Atheism, from which The Brothers Karamazov (with the "Legend of the Grand Inquisitor" as its part) later developed. And the Inquisitor in the novel, as the writer says through the words of Alyosha Karamazov, does not really believe in God, in fact, he is an atheistic Catholic, the personification of the depravity of the pope's claims to universal power and the perniciousness of socialist teachings that promise people material abundance without any connection with spiritual health.

In "The Sentence", "the terrible host of the princes of the empire", "cardinals and prelates", having condemned Huss, argue about which kind of execution to put the heretic to. And then they are ambushed by an unexpected temptation:

\section{The fact is that at this time}

Suddenly he began to sing in a lilac bush

The Nightingale before the Dark Castle,

celebrating Spring evening;

\section{He sang - and everyone remembered}

A nightingale like that for sure,

Who's in Naples, who's in Prague,

Who is over the Rhine at the appointed hour... [5. P. 325-329]

Here the Catholic hierarchs took the voice of God, the call to mercy, unconsciously provoked by the singing of the nightingale - the bird of God, for a diabolical delusion. To the "Golden Days of Freedom" they preferred following a dogma, a good impulse of the soul - the execution of one whose only crime was freedom of thought. The Hermit Cardinal from "The Sentence" is the forerunner of the Grand Inquisitor in The Brothers Karamazov.

Maykov endowed his hero with a belief in his own choice, in a special closeness to God by virtue of many years of fasting and prayer in the desert, 
thanks to the "rigor of life", a belief in his right to punish heretics with death; Dostoevsky, on the contrary, forced the Grand Inquisitor to give up his choice, the freedom which he almost found in the desert, for the sake of gaining power over the masses - inquisitorial autodafe and material temptations, bread instead of faith.

In Maykov's case, the victim of the Inquisition is a real human person, a forerunner of the Protestant Reformation, a man of the same type as the participants of the Council of Constance in the Western world, although a Slav Gus here is by no means a new incarnation of Christ, his fate is only an occasion for God's call to mercy, which the old cardinal and his comrades were able to stifle in their hearts and present it as the devil's machinations.

In Dostoevsky's case, the action has already been transferred to the Reformation era, to Spain. The opponent of the Grand Inquisitor is already Jesus Christ himself. And in the end, the only kiss of his silent captive becomes stronger than all the, seemingly, logically perfect arguments of the elder. This kiss prompts the Grand Inquisitor to release Christ. The whole coherent system of arguments collapses as a result of one manifestation of love and kindness, although the Grand Inquisitor does not renounce his views.

In a letter to Maykov dated January 18, 1856 from Semipalatinsk, Dostoevsky praised Maykov's poem "The Clermont Council”, written in 1854 in connection with the Crimean War: "I read your poems and found them beautiful; I fully share with you the patriotic feeling of the moral liberation of the Slavs. This is the role of Russia, the noble, great Russia, our holy mother. How good is the ending, the last lines in your 'The Clermont Council'! Where did you get such a language to express such a great idea so magnificently? Yes, I share with you the idea that Russia will surmount Europe and its role. It's been clear to me for a long time" [1. Vol. 28. Book 1. P. 208]. This poem is also reflected in "The Legend of the Grand Inquisitor".

In "The Legend of the Clermont Council", at the call of Pope Urban II, voiced on November 26, 1095, going on a crusade against the Muslims for the liberation of Jerusalem, a pilgrim - a hermit from the East, who escaped from Muslim captivity, speaks before the knights:

God himself, who rules us,

Bowed to my poverty

And he commanded me to stand before you,

And to you in heartfelt simplicity

To say about the captivity, about those torments,

What I have experienced and seen. [4. P. 13-16]

Christ is captured by the Grand Inquisitor, just as the pilgrim hermit and the newly revealed Christ in Maykov are captured by the Muslims. In Dostoevsky, "the guard leads the prisoner to a narrow and gloomy vaulted prison in the ancient building of the holy court and locks him in it" [1. Vol. 14. P. 227], while in 
Maykov's poem, the prisoner pilgrim, speaking on behalf of Christ, remains "in the dungeons of stuffy and damp". It is characteristic that, like Maykov, Dostoevsky calls Christ a prisoner. The pilgrim recalls: "I dragged the stones through the hot steppe". The Inquisitor addresses Christ: "Do you see these stones in this naked, hot desert? Turn them into loaves, and mankind will run after you like a flock, grateful and obedient, though always trembling that you will take your hand and your loaves will cease for them" [1. Vol. 14. P. 230]. The motif of stones being turned into bread comes not only from the Gospel of Matthew (4:3), but also from the poem of Maykov, which also probably focuses on the gospel source. The Grand Inquisitor says of the people: "They will be amazed and horrified at us and proud that we are so powerful and so clever that we could subdue such a violent herd of thousands of millions" [1. Vol. 14. P. 236].

We read in Maykov's poem: "And the Turk prowled through the desert, / Like a drover in front of a herd" [4. P. 14]. Perhaps these lines, comparing the captives being chased through the desert with cattle, inspired Dostoevsky to make Fyodor Karamazov a major cattle dealer, and make the fictional city of Skotoprigonyevsk the scene of The Brothers Karamazov, although Staraya Russa, where Dostoevsky lived in the last years of his life and from which Skotoprigonyevsk was largely written off, was never a major center of cattle trade. And Ivan Fyodorovich Karamazov, the author of the poem about the Grand Inquisitor, remembers the Turkish atrocities in Bulgaria [1. Vol. 14. P. 217].

The Inquisitor addresses Christ and points out that "you judged people too highly, for, of course, they are slaves, although they were created by rebels" [1. Vol. 14. P. 233]. In Maykov's poem, the pilgrim addresses the people:

\section{Oh, impressionable children! \\ How cheap your tears are! \\ Oh, to touch you, the sufferers \\ Should appear as beggars? \\ To assure you, it is necessary to let you \\ Feel the sores! [6. P. 13]}

The Inquisitor claims that the human person is "weak and mean". [1. Vol. 14. P. 233] And all the pathos of Maykov's poem is directed against the man of the West, who once rose in the crusades for the faith against the Muslims, and now, together with the Turkish sultan, is fighting against Russia. This motif was embodied in the words of the Grand Inquisitor.

People, according to the Grand Inquisitor, "will overthrow the temples and pour blood on the earth" [1. Vol. 14. P. 233]. Thus, they are like the Muslims who left "Holy Temples without crosses" in Jerusalem.

The Inquisitor threatens Christ: "What I say to you will come true, and our kingdom will be built. I repeat to you, to-morrow you will see this obedient flock, which at the first wave of my hand will rush to rake hot coals to your fire, on which I will burn you for coming to disturb us. For if there was anyone who 
deserved our bonfire more than anyone else, it was you. I'll burn you tomorrow. Dixi". [1. Vol. 14. P. 237]. In Maykov's poem "The Priest who sang the Psalm", "In pieces, a chopped up body / The villains threw at us" [4. P. 15]. In fact, we see breaking on the wheel. And it is such an execution that is originally proposed for Gus in the "Sentence" ("He offered to the Council / To execute him by a wheel") [3. P. 325], which emphasizes the connection between the two poems.

\section{Conclusion}

If the cardinal hermit from "The Legend of the Constance Council" became the prototype of the Grand Inquisitor, then the pilgrim hermit from "The Legend of the Clermont Council" became the prototype of the unrecognized Christ in "The Legend of the Grand Inquisitor". And "The Legend of the Spanish Inquisition" suggested moving the action of Ivan Karamazov's poem to Seville, as well as giving some details of the image of General Vorokhov's widow.

\section{Библиографический список}

[1] Достоевский Ф.М. Полное собрание сочинений в 30 т. / под ред. В.Г. Базанова. Л.: Наука, 1972-1990.

[2] Нечаева В.С. Журнал М.М. и Ф.М. Достоевских «Время». 1861-1863. М.: Наука, 1972. $316 \mathrm{c}$.

[3] Майков А.Н. Избранные сочинения / вступ. ст. Ф.Я. Прийма; под ред. Л.С. Гейро. Л.: Сов. Писатель, 1977. 246 с.

[4] Соколов Б.В. Россия и Запад: в тени Великого инквизитора // Грани. М., 1997. № 184. C. $10-27$.

[5] Майков А.Н. Сочинения: в 2 т. / под ред. Ф.Я. Прйимы. М.: Правда, 1984. Т. 1. 587 с.

[6] Майков А.Н. 1854-й год. Стихотворения. СПб.: Императорская Академия наук, 1854. 53 с.

\section{References}

[1] Dostoevsky, F.M. (1972-1990). Complete collection of works. Leningrad: Nauka Publ. (In Russ.)

[2] Nechaeva, V.S. (1972). Journal of M.M. and F.M. Dostoevsky "Vremya”. 1861-1863. Moscow: Nauka Publ. (In Russ.)

[3] Maykov, A.N. (1977). Selected works. Leningrad: Sov. Writer Publ. (In Russ.)

[4] Sokolov, B.V. (1997). Russia and the West: in the Shadow of the Grand Inquisitor. In Facets, 184, 10-27. (In Russ.)

[5] Maykov, A.N. (1984). Works. (Vol. 1). Moscow: Pravda Publ. (In Russ.)

[6] Maykov, A.N. (1854). 1854-th year. Poems. St. Petersburg: Imperial Academy of Sciences Publ. (In Russ.)

\section{Bio note:}

Boris V. Sokolov, PhD of Philology. ORCID: 0000-0001-8147-4918; e-mail: bvsokolov@yandex.ru

\section{Сведения об авторе:}

Соколов Борис Вадимович, доктор филологических наук. ORCID: 0000-0001-8147-4918; e-mail: bvsokolov@yandex.ru. 